\title{
Urinary nicotine concentrations in cigarette and pipe smokers
}

\author{
NICHOLAS J WALD, MARIANNE IDLE, JILLIAN BOREHAM, ALAN BAILEY, \\ HELEN VAN VUNAKIS
}

From the Imperial Cancer Research Fund Cancer Epidemiology and Clinical Trials Unit, Radcliffe Infirmary, Oxford; BUPA Medical Research, London; and the Graduate Department of Biochemistry, Brandeis University, Waltham, Massachusetts, USA

ABSTRACT Urinary concentrations of nicotine were studied in men who did not smoke (27) and in men who smoked cigarettes only (145) or pipes only (48). The median urinary nicotine concentrations were less than $50 \mathrm{ng} / \mathrm{ml}$ (the detection limit of the assay for urine tests) in the non-smokers, $1393 \mathrm{ng} / \mathrm{ml}$ in the cigarette smokers, and $1048 \mathrm{ng} / \mathrm{ml}$ in the pipe smokers. These values were standardised for urinary $\mathrm{pH}$ and creatinine concentration to allow for the fact that nicotine excretion is influenced by the acidity of the urine and by urinary flow rate. The high urinary nicotine concentrations in the pipe and cigarette smokers indicated that both types of smoker have relatively high systemic nicotine concentrations. This observation, together with the fact that large prospective studies have shown that pipe smokers have no material excess risk of coronary heart disease whereas cigarette smokers do, provides evidence that nicotine is unlikely to be the major cause of the excess deaths from coronary heart disease in cigarette smokers. This conclusion is consistent with earlier observations based on serum cotinine concentrations in smokers and non-smokers.

We have suggested that nicotine is unlikely to be the major cause of the excess risk of heart disease in cigarette smokers.' This conclusion was based on the observation that pipe smokers have higher concentrations of serum cotinine (a major metabolite of nicotine) than do cigarette smokers, but have no material excess risk of heart disease. Our conclusion could not have been otherwise unless (1) nicotine were not metabolised to cotinine similarly in all smokers or (2) nicotine absorbed through the pulmonary alveoli were more toxic (perhaps on account of the route and rapid rate of absorption) than when absorbed through the buccal mucosa.

Jarvis and Russell ${ }^{2}$ speculated that pipe smokers do indeed metabolise nicotine differently from cigarette smokers, arguing that much of the nicotine from pipe smoke is swallowed in saliva and metabolised to cotinine in the liver before reaching the systemic circulation. This possibility can be investigated by seeing whether pipe smokers have high serum nicotine as well as cotinine concentrations; if they do, Jarvis and Russell's objection can be dismissed;

\footnotetext{
Address for reprint requests: Professor NJ Wald, Department of Environmental and Preventive Medicine, Medical College of St Bartholomew's Hospital, London EC1M 6BQ.
}

Accepted 16 January 1984 otherwise it is valid. A recognised difficulty with this direct approach arises because nicotine in the circulation has a half life no greater than about two hours. ${ }^{34}$ As a result a serum nicotine measurement will provide an unreliable indication of a person's average serum nicotine concentration, particularly if the circumstances of the examination at which the blood was collected were such as to make it difficult to smoke in the preceding few hours.

We therefore investigated the issue indirectly by performing urinary nicotine determinations on the cigarette and pipe smokers who were the subject of our previous report on cotinine concentrations in smokers. ${ }^{1}$ Since nicotine in the systemic circulation is excreted, unchanged, in the urine, urinary nicotine should, on average, reflect serum nicotine concentrations provided that other factors which may affect urinary nicotine concentrations, such as urinary flow and urinary $\mathrm{pH}$, can be satisfactorily allowed for or are not systematically different between the groups being compared.

\section{Methods}

We studied 27 men who were lifelong non-smokers, 145 men who smoked cigarettes only, and 48 men 
who smoked pipes only. All the men were included in our earlier study on serum cotinine concentrations. ${ }^{1}$ One non-smoker, three cigarette smokers, and two pipe smokers who were included in our earlier study could not be included in this one because of missing or insufficient urine samples. A further two cigarette smokers and six pipe smokers were excluded because they were found to have smoked other forms of tobacco. Excluding these eight from our previous analyses did not alter the conclusions. A $20 \mathrm{ml}$ sample of urine had been collected from each man at the screening examination during which the original blood sample was collected. The urine samples were retrieved from $-40^{\circ} \mathrm{C}$ storage, the $\mathrm{pH}$ was measured, and the nicotine concentration was determined by radioimmunoassay $^{5}$ (detection limit $50 \mathrm{ng} / \mathrm{ml}$ with a $1 / 10$ dilution of urine to eliminate non-specific effects). The creatinine concentration was measured with a modified Jaffe reaction. ${ }^{6}$

\section{Results}

The figure shows the cumulative distribution of urinary nicotine levels in cigarette and pipe smokers, the pipe smokers being classified according to whether they had never smoked cigarettes (primary) or whether they had previously smoked cigarettes (secondary). There is little difference in distribution between the different groups of smokers. All the non-smokers had concentrations less than the detection limit of the assay $(50 \mathrm{ng} / \mathrm{ml})$ and these results are not shown in the figure.

For a given serum nicotine concentration the urinary nicotine concentration is known to depend on urinary $\mathrm{pH}$ and on the rate of urine production, ${ }^{37}$ which can be approximately assessed from a urinary creatinine estimation. Our data confirm these associations; the median urinary nicotine concentrations in the $\mathrm{pH}$ groups $<6 \cdot 0,6 \cdot 0-6 \cdot 9$, and $\geqslant 7 \cdot 0$ were 3440,1180 , and $355 \mathrm{ng} / \mathrm{ml}$ in cigarette smokers and 2580,1170 , and $352 \mathrm{ng} / \mathrm{ml}$ in pipe smokers. The median urinary nicotine concentrations in the creatinine groups $<8 \cdot 5,8 \cdot 5-13 \cdot 4$, and $\geqslant 13.5 \mathrm{mmol} / \mathrm{l}$ $(<96,96-151$, and $\geqslant 152 \mathrm{mg} / 100 \mathrm{ml})$ were 830 , 1590 , and $1751 \mathrm{ng} / \mathrm{ml}$ in cigarette smokers and 255 , 1770 , and $2580 \mathrm{ng} / \mathrm{ml}$ in pipe smokers. All these trends were significant: $p<0 \cdot 05$. Although the distributions of urinary $\mathrm{pH}$ and creatinine concentrations were similar among cigarette and pipe smokers (table 1) they were not identical. In table 2, therefore, which shows urinary nicotine concentrations (25th and 75th percentiles and median) in cigarette and pipe smokers, results are presented both unstandardised and standardised for $\mathrm{pH}$ and creatinine. Standardisation was performed by the

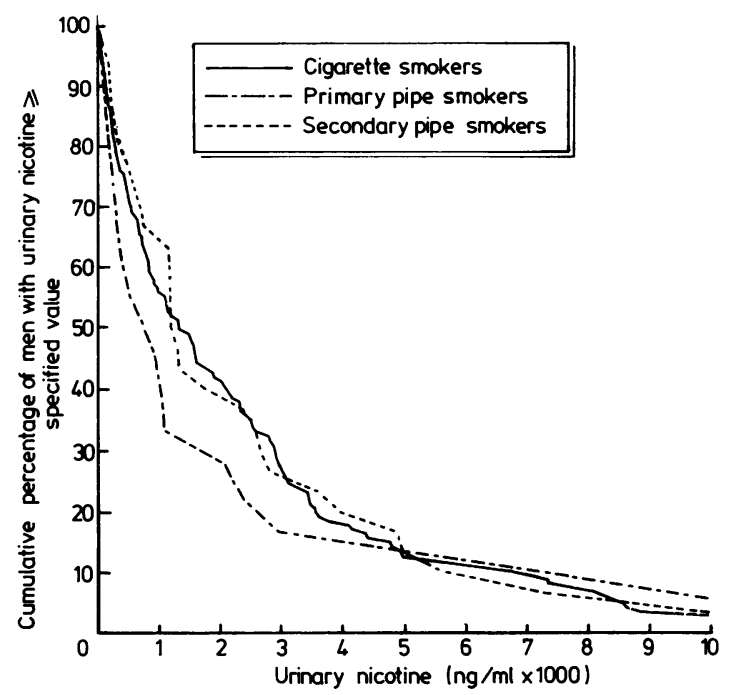

Cumulative distribution of urinary nicotine levels in cigarette and pipe smokers.

indirect $\operatorname{method}^{8}$ on the basis of the urinary $\mathrm{pH}$ and creatinine categories shown in table 1 , and smokers with detectable urinary nicotine concentrations were taken to be the standard population. This method of standardisation is widely used to allow for age in comparisons of disease or death rates in populations with different age distributions.

Table 2 also gives the results restricted to those who smoked on the day the urine sample was collected-the latter perhaps producing a fairer comparison of nicotine concentrations in the different groups of smokers, since most of the nicotine produced through smoking on a previous day is likely to have been excreted into the urine and voided before our samples could be collected.

Table 1 Distribution of urinary $\mathrm{pH}$ and creatinine according to type of smoker

\begin{tabular}{|c|c|c|c|}
\hline & \multicolumn{3}{|c|}{ No of men (\%) } \\
\hline & \multirow{2}{*}{$\begin{array}{l}\text { Cigarette } \\
\text { smokers }\end{array}$} & \multicolumn{2}{|c|}{ Pipe smokers } \\
\hline & & Primary & Secondary \\
\hline All & $145(100)$ & $18(100)$ & $30(100)$ \\
\hline $\begin{array}{c}\text { Urinary } \mathrm{pH} \\
<6 \cdot 0 \\
6 \cdot 0-6 \cdot 9 \\
\geqslant 7 \cdot 0\end{array}$ & $\begin{array}{l}53(37) \\
52(36) \\
40(28)\end{array}$ & $\begin{array}{l}4(22) \\
7(39) \\
7(39)\end{array}$ & $\begin{array}{r}13(43) \\
10(33) \\
7(23)\end{array}$ \\
\hline $\begin{array}{l}\text { Urinary cre } \\
<8.5 \\
8.5-13.4 \\
\geqslant 13.5\end{array}$ & $\begin{array}{l}\text { 1ol/l) } \\
51(35) \\
48(33) \\
46(32)\end{array}$ & $\begin{array}{l}6(33) \\
8(44) \\
4(22)\end{array}$ & $\begin{array}{r}10(33) \\
9(30) \\
11(37)\end{array}$ \\
\hline
\end{tabular}

Conversion: SI to traditional units_Urinary creatinine: $1 \mathrm{mmol} / 1 \approx$ $11 \cdot 3 \mathrm{mg} / 100 \mathrm{ml}$. 
Table 2 Median and 25th and 75th percentiles of urinary nicotine concentrations according to type of smoker

\begin{tabular}{|c|c|c|c|c|c|}
\hline & & \multirow{2}{*}{$\begin{array}{l}\text { Cigarette } \\
\text { smokers }\end{array}$} & \multicolumn{3}{|c|}{ Pipe smokers } \\
\hline & & & Primary & Secondary & All \\
\hline $\begin{array}{l}\text { All smokers } \\
\text { No of men } \\
\text { Urinary nicotine }(\mathrm{ng} / \mathrm{ml})\end{array}$ & & 145 & 18 & 30 & 48 \\
\hline $\begin{array}{l}\text { 25th percentile } \\
\text { Median } \\
\text { 75th percentile }\end{array}$ & $\begin{array}{l}\text { standardised }{ }^{*} \\
\text { unstandardised } \\
\text { standardised }{ }^{*} \\
\text { unstandardised } \\
\text { standardised }{ }^{*} \\
\text { unstandardised }\end{array}$ & $\begin{array}{r}733 \\
421 \\
1393 \\
1310 \\
2505 \\
3082\end{array}$ & $\begin{array}{r}<50 \\
<50 \\
994 \\
623 \\
1705 \\
2070\end{array}$ & $\begin{array}{r}520 \\
490 \\
1048 \\
1200 \\
2711 \\
2820\end{array}$ & $\begin{array}{r}433 \\
289 \\
1048 \\
1110 \\
2516 \\
2620\end{array}$ \\
\hline $\begin{array}{l}\text { Men who had smoked on } \\
\text { No of men } \\
\text { Urinary nicotine }(\mathrm{ng} / \mathrm{ml})\end{array}$ & urine sample was collected & 128 & 14 & 28 & 42 \\
\hline $\begin{array}{l}\text { 25th percentile } \\
\text { Median } \\
\text { 75th percentile }\end{array}$ & $\begin{array}{l}\text { standardised* } \\
\text { unstandardised } \\
\text { standardised }^{*} \\
\text { unstandardised } \\
\text { standardised* } \\
\text { unstandardised }\end{array}$ & $\begin{array}{r}975 \\
590 \\
1509 \\
1590 \\
2696 \\
3440\end{array}$ & $\begin{array}{r}735 \\
400 \\
1286 \\
999 \\
2467 \\
2380\end{array}$ & $\begin{array}{r}598 \\
408 \\
1098 \\
1200 \\
2735 \\
3086\end{array}$ & $\begin{array}{r}688 \\
400 \\
1206 \\
1175 \\
2641 \\
2660\end{array}$ \\
\hline
\end{tabular}

${ }^{*}$ Standardised for urinary $\mathrm{pH}$ and creatinine on the basis of the $\mathrm{pH}$ and creatinine categories shown in table 1 . Urinary nicotine values below the detection limit of the assay $(50 \mathrm{ng} / \mathrm{ml})$ were excluded from the standardisation procedure and set to $10 \mathrm{ng} / \mathrm{ml}$.

Among those who did smoke on the day urine was collected the standardised median nicotine concentration for pipe smokers was $1206 \mathrm{ng} / \mathrm{ml}$, which, although somewhat lower than the nicotine concentration of $1509 \mathrm{ng} / \mathrm{ml}$ for cigarette smokers, was much higher than the concentration among non-smokers, all of whom had levels below the detection limit of the assay $(50 \mathrm{ng} / \mathrm{ml})$. The standardised median nicotine concentration in primary pipe smokers was lower than that among the secondary pipe smokers, although the difference was not great; and both types of pipe smoker had considerably greater median nicotine concentrations than non-smokers. From these results and our earlier demonstration of high serum cotinine concentrations in pipe smokers, it appears that serum cotinine concentrations are a reasonable measure of systemic nicotine exposure. To investigate this formally we performed multiple linear regression of urinary nicotine on serum cotinine, urinary $\mathrm{pH}$, and urinary creatinine (nicotine and cotinine being expressed in logarithms). This showed that in both pipe smokers and cigarette smokers there was a highly significant association between serum cotinine and urinary nicotine when urinary $\mathrm{pH}$ and creatinine were allowed for $\left(\mathrm{r}^{2}\right.$ for cigarette smokers, primary pipe smokers, secondary pipe smokers, and all pipe smokers combined was respectively $0.72,0.51$, 0.52 , and 0.53 ; in each case $p<0.05$ ).

\section{Discussion}

We have previously reported that this sample of pipe smokers had a high average serum cotinine concentration.' Since we have now found that they had a high average urinary nicotine concentration as well, we can dismiss the hypothesis that nicotine from pipe smoke is largely swallowed in saliva and metabolised to cotinine in the liver before reaching the systemic circulation. As has been suggested before, most is probably absorbed through the epithelial mucosa of the mouth and tongue. Some of the nicotine we measured may have arisen from swallowed nicotine that either passed directly through the liver or was metabolised in the liver to nicotine $N^{\prime}$ oxide and then enzymatically reduced to nicotine in other tissues before entering the systemic circulation. Either way, urinary nicotine is a valid indication of systemic nicotine concentrations. We can be reasonably confident that nicotine was not derived from cotinine since there is no evidence that this reaction can occur in vivo.

Our data show that pipe smokers obtained high systemic concentrations of nicotine, which were about two thirds the concentrations found in cigarette smokers. Unlike cigarette smokers, pipe smokers have no material excess risk of coronary heart disease,' so we can be reasonably confident that exposure to high systemic concentrations of nicotine is not a cause of the disease. We know that the inhaling patterns of pipe and cigarette smokers are different and there are therefore also likely to be differences in the absorption of nicotine. Some of the nicotine will arise from exposure to sidestream as well as mainstream smoke, and the proportions may differ between pipe and cigarette smokers. As 
we have already pointed out, ${ }^{19}$ we cannot exclude the possibility that nicotine might exert a toxic effect on the cardiovascular system by a "pulse" effectthat is, through sudden high levels of nicotine, such as can be achieved by the inhalation of cigarette smoke, producing outpourings of, say, adrenal hormones, which could be the direct cause of the cardiovascular damage. What we have demonstrated is that the effect cannot be due to the total systemic exposure to nicotine. Thus, while our data cannot completely exonerate nicotine, they do substantially reduce the weight of evidence suggesting that nicotine is a cause of coronary heart disease.

We thank the Medical Research Council for contributing to the financial support of the study of BUPA men. The nicotine assays were done with support from the National Institute on Drug Abuse (DAO2507). HVV is the recipient of a US Public Health Service research career award (5K6A12372). The creatinine estimations were performed in the clinical chemistry department, Queen Elizabeth Hospital, Birmingham. Until the end of February 1983 JB was a Laing research fellow in preventive medicine.

\section{References}

' Wald NJ, Idle M, Boreham J, Bailey A, Van Vunakis H. Serum cotinine levels in pipe smokers: evidence against nicotine as cause of coronary heart disease. Lancet 1981;ii:775-7.

2 Jarvis MJ, Russell MAH. Nicotine, carbon monoxide and heart disease. Lancet 1982;ii: 1045.

${ }^{3}$ Russell MAH, Feyerabend C. Cigarette smoking: a dependence on high-nicotine boli. Drug Metabolism Reviews 1978; 9 (1):29-57.

${ }^{4}$ Benowitz NL, Peyton J, Reese TJ, Rosenberg J. Interindividual variability in the metabolism and cardiovascular effects of nicotine in man.J Pharmacol Exp Ther 1982;221:368-72.

${ }^{5}$ Langone JJ, Gijika HB, Van Vunakis H. Nicotine and its metabolites. Radioimmunoassays for nicotine and cotinine. Biochemistry 1973;12:5025-30.

- White WA, Attwood EZ. An improved continuous flow method for serum creatinine using a Jaffe reaction. Ann Clin Biochem 1980;17:153-4.

' Beckett AH, Gorrod JW, Jenner P. The analysis of nicotine- $\mathrm{I}^{\prime}-\mathrm{N}$-oxide in urine in the presence of nicotine and cotinine and its application to the study of in vivo nicotine metabolism in man. $J$ Pharmacol Pharmacol 1971;23:55S-61S.

${ }^{8}$ Bradford Hill A. A short textbook of medical statistics. London: Hodder and Stoughton, 1977:181-98.

9 Wald NJ, Idle M, Boreham J, Bailey A, Van Vunakis H. Nicotine, carbon monoxide and heart disease. Lancet 1982;i:40-1. 